\title{
Determinants of National Saving in Ethiopia
}

\author{
Deresa Tolesa \\ Lecturer, Department of Economics Metu University, Ethiopia \\ Tesfaye Melaku \\ Lecturer and Researcher, Department of Economics, Jimma University, Ethiopia
}

\begin{abstract}
This research investigates the determinants of national saving in Ethiopia over the period 1984-2014. The main objective of the study is to identify the major factors that determine national saving in Ethiopia. The ordinary least square estimation method is used to arrive at the results of the study. The result of the long run and short run models revealed that Real Gross Domestic product, investment, consumption and inflation have shown similar relationship in both models. Real Gross Demotic product is the only factor which affects national saving significantly and positively. Other factors, which positively affect national saving, are not much significant. Example, investment, consumption and inflation are factors which affects national saving both positively and in significantly in the end.
\end{abstract}

DOI: $10.7176 / \mathrm{JESD} / 11-21-04$

Publication date: November $30^{\text {th }} 2020$

\subsection{Background of the study}

An economic system must be able to produce capital if it is to satisfy the want and needs of its citizens. To create capital, people must be willing to save, which release product for use elsewhere. When people save, they make funds available to others and when business borrows these savings, new business and services are created, plants and equipment are produced and new jobs become accessible (William, 2003). Mankiew (2000) puts the prominence of distribution of economic resources as; the behavior of economic mediators in the allocation of economic resources is a critical feature that exerts influence on the growth path of a country. The first of such allocation issue is concerned with the inter-temporal allocation of income between consumption and saving.

The behavior and contributing factor of such allocation decision are important to understand the mechanisms and interactions across aggregate consumption, saving, capital accumulation and growth processes, in fact, economic policies in most countries try to influence the level and growth of these variables so as to achieve growth and development for any a nation. The efficiency of such policies still depends on the nature and degree of influence and impact that various policies may have on macroeconomic variables (Mankiew, 2000).

In any nation, aggregate saving has three components, these are national saving, corporate saving followed by public savings (Kumarasinghe, 2007). The contribution of these saving is a very important factor in bringing economic development. But different factors have various effects on national saving either in the negative or positive sense.

In order to achieve the millennium development goals, the issue of saving has become a point of emphasis for Ethiopia. The government is planning to mobilize domestic resource in order to finance a relatively huge amount of investment in infrastructure as stipulated in the new growth and transformation plan (MOFED, 2010).

To keep macroeconomic balance, the government has designed a policy to increase financial resource through the mobilization of domestic saving. It is actually designing different measures to indicate people to save. Some of these measures to encourage saving includes Diaspora bond, housing related saving schemes, the grand Ethiopian renaissances dam bond saving schemes, adjusting the interest rates and consolidation of person and provident funds (NBE, 2010). So, this study is important in exploring factors that are affect national saving in Ethiopia.

Economic growth is the primary target of all countries of the world including least developing countries. Among other things, growth in Real Gross Domestic Product is a first-class indicator of economic growth; higher RGDP implies higher income and thus higher standard of living, and of course higher growth rate of GDP. One of the vital ingredients of GDP is saving. Saving rates around the world is very widely practiced. Current statistics indicates that, on average East Asia saves more than 30\% of their gross national disposable income but sub-Saharan African countries saves less than 15\%. According to (Ezega, 2011), Ethiopia is falling in a sort of trap as it is not saving enough as a nation and just depending on foreign investment to boost its growth. Thus, to achieve the five years growth and transformation plan and MDGs, Ethiopia has to increase saving rate. Saving has a direct and positive relationship with GDP. Therefore, attempts to increase GDP which increase economic growth rely highly on saving.

In developed economies, saving has a larger part in total output and its growth rate is high. Thus, it can be said that saving has a immense contribution to growth rate of an economy. The experience in developing countries 
in recent years has also demonstrated that achieving gains in real per capital incomes requires more saving. Nonetheless, saving in developing countries is significantly lower than in other countries and still too low to support a sustainable expansion in output and employment. In Ethiopia, low saving has always been the dominant feature of the Ethiopian economy even after various policy reforms undertaken to encourage it by government. (EEA, 2011)

This study focuses on the determinants of national saving in Ethiopia by using relatively the newest (updated) data available now a day. Here, it means that, the data that the researcher employed in this study is based on the current data, which is important to know or to study the effects of the determinants of national saving in Ethiopia at current situation after reforms were taken. To summarize, this research discuss on the determinants of national saving in Ethiopia by using data from 1984-2014/15 which can give us updated information about the current status of national saving determinants.

The main reason for choosing this time interval is that most of the data that is available for the study and have been available in a sophisticated manner and well organized condition since 1984 and the reason for choosing $2014 / 15$ as the upper limit is to get finished and well organized recent data from different sources, and to understand the current situation of national saving in Ethiopia.

However, national saving level in Ethiopia is very low and little is known empirically about its patterns and determinants. Therefore, this study attempts to identify and analyze the main determinants of national saving in Ethiopia. The basic questions that that were answered among others includes; what is the importance of national saving? Which economic variables can affect national saving?, and what is the impact or effect of these variables on national saving?

The objective of this study was to identify the major factors that determine national saving in Ethiopian. Specifically, to investigate trends and performance of national saving and to identify variables that could affect national saving.

\section{Literature Review: Empirical Evidence}

There are vast amount of empirical literature examining the determinants of national saving, and link between national saving and aggregate investment. In addition, investigation of saving behavior has gained significance in the empirical studies, although the lack of complete and reliable data (Hebbel, et al, 1996). For the sake of an excellent survey of saving, lack of reliable date is the main bottleneck.

The rate of saving, from global perspective, has exhibited a downward trend over the past four decades. The oil-shocks and the subsequent recessions and declines in the growth rate constitute the main elucidation behind such global variations in saving rates. Least developing countries registered relatively lower rate of saving than developed nations and among those developing countries those with fast economic growth rate registered significantly increase in the national saving. Whereas most regional economies either increased or maintained their saving performance, sub-Saharan African countries missed their ground in their both saving rate as well as growth rate enactment. The region is exceptional in a sense that is saving rate has been not only low but also declining over the last four decades (Girma, 2004)

Ghulati and Thiman (1997) Examined empirical determinants of national savings for a sample of economies in south East Asia and Latin America over the period 1975-1995, they used panel-estimation to examine association between national saving rates and policy and non-policy variables. Their results indicates that fiscal policy, particularly social security arrangements influence national savings; macroeconomic stability and financial deepening also appear as important variables influencing saving behavior in the regions.

Tochukwu and Fetus (2007) scrutinize the determinants of national saving in Nigeria and they compared the estimation results of the error-correction model with those of three conventional models: Partial adjustment, Growth rate and Static models.

They found and concluded that the error correction model performs much better than the other models. Their results disclose that the saving rate rises with the level of disposable income but falls with the rate of growth of disposable income. The real interest rate on bank deposits has a significant negative impact on, while public saving seems not too crowd-out national saving. Also, external terms of trade, inflation rate and external debt service ratio have a positive impact on national saving.

Prema (2003) surveys the determinants of national saving in the process of economic development, in the Indian experience. He found that the saving rate rises with both the level and the rate of growth of disposable income. Prema (2003) found that real interest rate on Bank deposits has significant positive impact but the extent of the impact is modest, public saving seems to crowed out national saving, but less than proportionately. Moreover, the spread of banking facilities in the economy and inflation rate have a positive impact and changes in the external terms of trade a negative impact on national saving.

Cloudio and Sarwet (2003) investigated those empirical determinants of national saving in Brazil over the period 1965-2000. Their finding reveal that national saving have publicized a relatively high and inverse response to public saving, with econometric estimates for the period 1965-2000 suggesting that a one percentage point 
increase in the ratio of public saving to GDP increased gross national saving by about 0.2 percentage point of GDP in the long run. This result is in the line with estimates for other Latin American countries. They also found that fiscal consolidation appears as one of the best policy instruments to raise the national saving rate in Brazil. They examined also increasing financial deepening has a positive impact on the saving rate. Finally, there finding also go in line with the international evidence in showing that the external terms of trade have a positive impact on national saving. These variables can be influenced in directly by trade diversification.

Hallaq (2003) analyzes and examines the determinants of national savings in Jordan during 1976-2000; the main results of Hallaq (2003) study are as follows: the size effect of the dependency ratio on national saving is found out negative and significant, government savings depress national savings in less than one to one fashion, though growth influences national savings through to channels the direct positive association between GDP gross rate and national savings, and the significant positive effect of the level GDP per capital income.

The development of Jordan consumer's credit market has a positive effect on national savings. Whereas, the significant affect the level of national savings, and finally, the real interest rate, inflation rate and terms of trade have insignificant impact on the level of national saving in Jordan.

Bjorn Anderson (1996), estimated saving and GDP in vicariate vector autoregressive or vector errorcorrection models for Sweden, UK and USA, and testes of granger non-causality are performed within the estimated systems. The main results shows that the casual chains linking saving and output differ across countries, and that causality associated with adjustments to long-run relations might go in different directions than causality associated with short-term disturbances.

Saving rate in Ethiopia has been very low and declined over time. During 1960-2003, the average domestic saving rate has been only 5.4 percent of GDP. Not only was the average saving rate has been low relative to income, it exhibits a declining trend. The average saving rate was about 14 percent of GDP during the period 1960/11974/75 and declined to nearly 7 percent during the Derge regime. On balance, what we end up having during the Derge was not an increase on the saving and investment ratios compared with previous regime. What we achieved during the Derge was tremendous fluctuations, and the saving rate collapsed to about a mere 3.7 percent during 1991/2-2002/3.

The recent rate of saving is too low by the country's own standard and relative to other developing countries. The economy witnessed a saving transition in 1974 that reduced the saving rate consistently leading a collapse of national saving rate that has never managed to reverse. The trend has also made the economy increasingly dependent on external financing, with excessive exposure to external shocks, and delaying the necessary reforms to create conducive investment to the national sector and put the economy on the sustainable path of growth and financing. (Girma, 2004)

\section{Research Methodology}

A time series data ranging from 1984 to $2014 / 15$ is used in this study to show the extent of relation between national saving and its determinants both in the descriptive and econometric analysis.

All the data are gathered from secondary sources. Most of the data's are taken from the Ethiopian economics Association database and from the national bank of Ethiopia. In addition, the quarterly bulletins and annual reports of commercial bank of Ethiopia, International monetary fund (IMF) and World Bank are used as a source of data.

To show the effect of different factors on national saving, a descriptive analysis is used. Here the theoretical relationship of the factors and national saving and empirical situation is discussed. Graphs are used to make comparison between different effects of these factors under different policy frame works and to show what kind of trend exists between them and national saving. Finally, econometric analysis is employed to capture the degree of influences of some of the determinants of national saving in Ethiopia.

In developing a saving model, it is difficult to include all the determinants of national saving because of unavailability of all the data required and non-quant able of some determinants. The saving model includes the following explanatory variables in the form of multiple linear regression function.

$\mathrm{S}=\mathrm{b}_{1}+\mathrm{b}_{2} \mathrm{RGDP}+\mathrm{b}_{3} \mathrm{INF}+\mathrm{b}_{4} \mathrm{C}+\mathrm{b}_{5}$ INVEST $+\mathrm{e}$

Where; $\mathrm{S}=$ national savings, RGDP=Real Gross Domestic Product, INF = Inflation, $\mathrm{C}=$ consumption, INVEST $=$ Investment

Summary of variables and their expected sign

\begin{tabular}{ll}
\hline Variables & Expected sign \\
Real Gross Domestic Product & + \\
Inflation & - \\
Investment & + \\
Consumption & -
\end{tabular}

Consumption

In order to assure the validity of the OLS estimation, checking the validity or nature of time series data is very important. For this purpose, stationary test is conducted. For valid estimations of OLS, the time series data itself has to be stationary; otherwise, using OLS estimation technique with a non-stationary time series data would 
be senseless. Thus, to make sure that stationerity condition has been fulfilled unit root test is under taken. Moreover, the study employ diagnostic tests like unit root test, multi-co-linearity test, autocorrelation test and co-integration test to show the validity of the model that the study used.

\section{Data Analysis and Discussion}

\subsection{Trends and descriptive analysis}

As we see from the figure 4.1, saving in Ethiopia was relatively low in the beginnings of 1980,s than the later years. It was sharply increasing from the year 1992-2000. After that it started declining at the beginning of 2001, and in 2003 it recovers. In recent years, there is no much fluctuation in saving in Ethiopia. These decline and rise of saving in different years is the result of the impacts of varieties of economic variables, which affects saving in Ethiopia. For instance, inflation rate around the year 2003 was nearly 15, which was one of the highest inflationary levels in Ethiopia. This might be one of the causes of a decline in saving in Ethiopia in these periods. In 2011/2012 saving in Ethiopia was relatively high which might be related with highest levels of RGDP, Saving rate, and level of investment which is $11.5,12$ and 10 respectively.

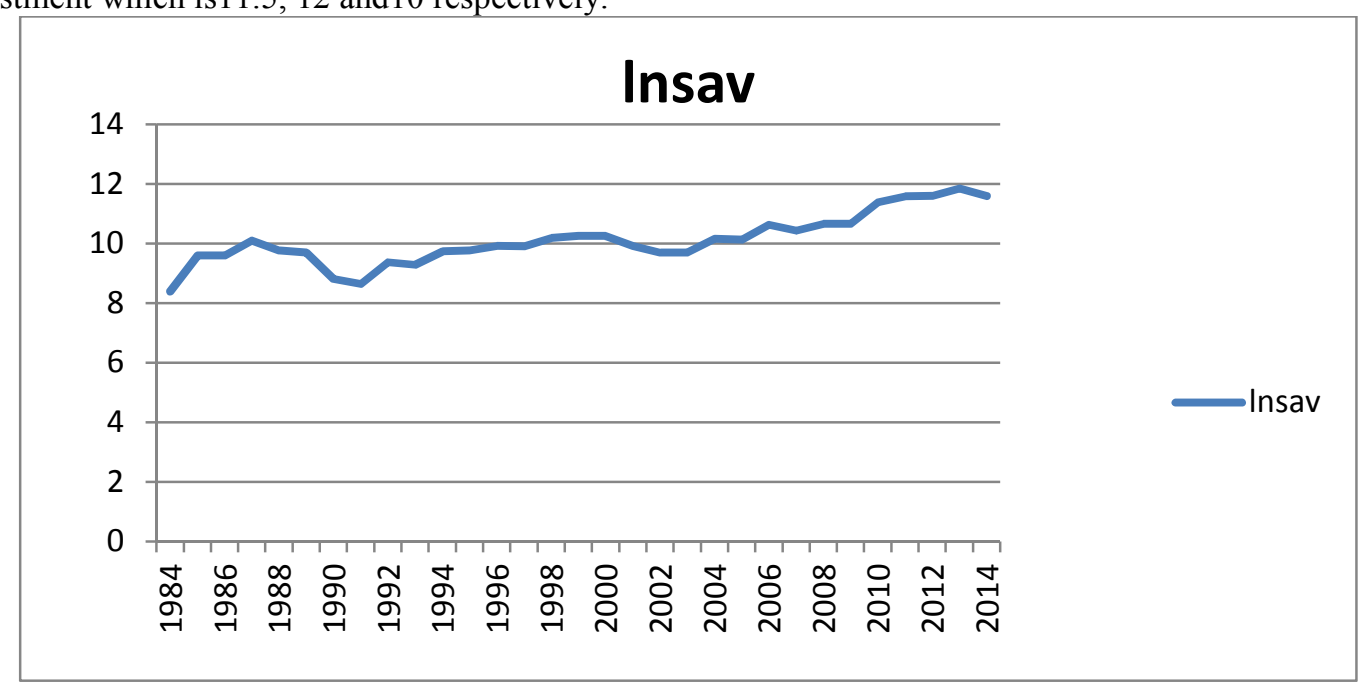

Figure 4.1: Trends of Saving In Ethiopia from $1984-2014$

\subsection{Trend of RGDP in Ethiopia from 1984-2014}

An increase in GDP has a positive effect on saving. This is due to the facts that increase in GDP leads to an increase in income. It is known from economic theories that as income increase the marginal propensity to consume out of the additional income decreases. Thus the higher the per capital income gets the share of consumption decreases and more out of the income will be saved.

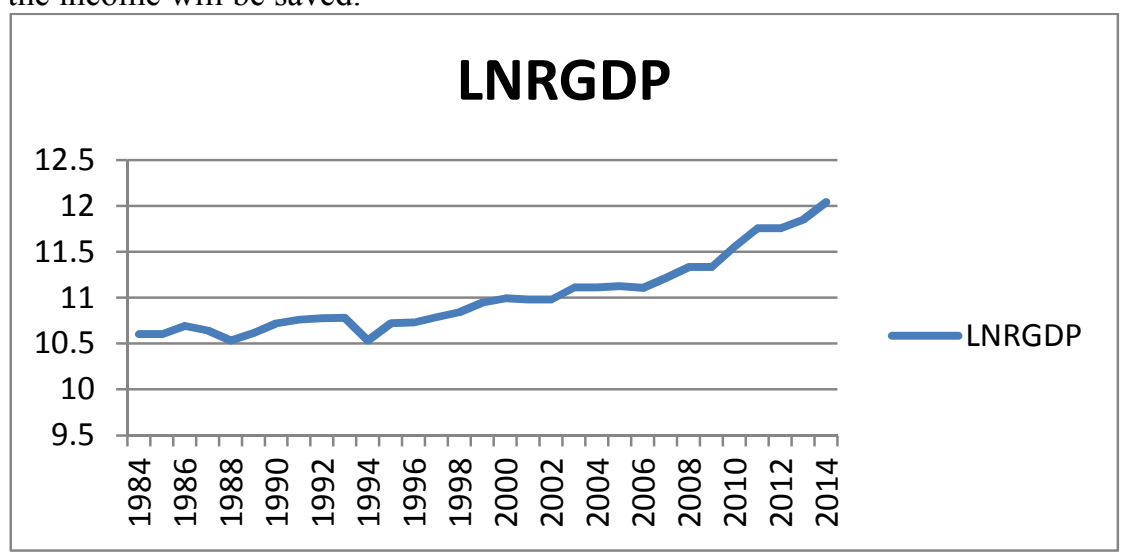

Figure 4.2. Trend of RGDP in Ethiopia from 1984-2014

As shown in the figure, during the period 1980's GDP shows a declining trend and it revived back after 1995.The lowest levels of GDP corresponds to the lowest levels of saving and the highest levels correspond to the highest levels of saving, which may lead us to conclude that there is a positive relationship between GDP and saving. 


\subsection{Result of Econometric Analysis}

Table 4.1. ADF-test result

Observation: 29 after adjustment

\begin{tabular}{llllllll}
\hline Variable & Null hypothesis & $\begin{array}{l}\text { Test } \\
\text { statistics }\end{array}$ & $\begin{array}{l}1 \% \\
\text { value }\end{array}$ & critical & $\begin{array}{l}5 \% \\
\text { value }\end{array}$ & critical & $10 \%$ \\
value & critical & $\begin{array}{l}\text { At } \\
(1)\end{array}$ \\
LNSAV & SAV has a unit root & -6.533 & -3.723 & -2.989 & -2.625 & $(1)$ \\
LNRGDP & RGDP has a unit root & -5.382 & -3.723 & -2.989 & -2.625 & $(1)$ \\
LN INV & INV has a unit root & -6.287 & -3.723 & -2.989 & -2.625 & $(1)$ \\
LNCONSUP & CONSUP has a unit & -7.256 & -3.723 & -2.989 & -2.625 & \\
INFL & root & & & & & & $(0)$ \\
\hline
\end{tabular}

Source: Own computation, 2017/18

All variables are stationary at all level of critical values. I.e. at $1 \%, 5 \%$ and $10 \%$ respectively

The presence of a unit root implies that the time series under investigation is non-stationary, while the absence of a unit root shows that the stochastic process is stationary.

The test has shown that saving, real gross domestic product, investment and consumption are not stationary at a level, while inflation is a stationary at a level. To make the variables stationary their first difference is taken. At the first difference saving, real gross domestic product (RGDP) investment (GCF), and consumption have become stationary.

\subsubsection{Result of Ordinary Least Square (OLS) Estimation}

LNSAVpt $=6.2494+0.8099$ LNRGDP pt +0.2513 LNINV pt +18.2456 LNCONSU pt +0.0088 INFL pt + Ut

The value of the constant term, 6.2494, which is significant and shows that saving, will have a value of 6.2494 million of birr, if all the explanatory variables (included in the model) are zero. It may also imply the impact of excluded variables of saving, other variables kept constant.

Other things remain constant as RGDP increases by one million birr saving increase by 0.8099 million Ethiopian birr. The relationship between saving and real gross product is positive. RGDP is positively affected saving. Investment is also positively affecting saving, as investment value increases by 1 unit saving increase by 0.2513 million of birr. Like the above two variables consumption and inflation positively affect saving of Ethiopia. Other things remain constant, as consumption increases by 1 unit, saving increases by 18.2456 million of birr. Other factors remain the same as inflation increase by $1 \%$ saving increases by 0.0088 million birr.

\subsubsection{Co-integration Test}

Table 4.2: Johnson Test results for co-integrating vectors (Unrestricted Co-integration Rank Test (Trace and Maximum Eigen-values Stata Results)

\begin{tabular}{llllllll}
$\begin{array}{l}\text { Ho: } \\
\text { (null) }\end{array}$ & $\begin{array}{l}\mathrm{H} 1: \\
\text { (altern) }\end{array}$ & $\begin{array}{l}\text { Eigen } \\
\text { value }\end{array}$ & $\begin{array}{l}\text { Trace } \\
\text { Statistic }\end{array}$ & $\begin{array}{l}0.05 \\
\text { Critical } \\
\text { Value }\end{array}$ & $\begin{array}{l}\text { Eigen } \\
\text { value }\end{array}$ & $\begin{array}{l}\text { Max- } \\
\text { Eigen } \\
\text { Statistic }\end{array}$ & $\begin{array}{l}0.05 \\
\text { Critical } \\
\text { Value }\end{array}$ \\
$\mathrm{r}=0^{*}$ & $\mathrm{r}=1$ & 0.81697 & 89.9215 & 68.52 & 0.81697 & 47.5472 & 33.46 \\
$\mathrm{r} \leq 1$ & $\mathrm{r}=2$ & 0.54931 & 42.3743 & 47.21 & 0.54931 & 22.3155 & 27.07 \\
$\mathrm{r} \leq 2$ & $\mathrm{r}=3$ & 0.35084 & 20.0588 & 29.68 & 0.35084 & 12.0983 & 20.97 \\
$\mathrm{r} \leq 3$ & $\mathrm{r}=4$ & 0.24734 & 7.9606 & 15.41 & 0.24734 & 7.9560 & 14.07 \\
$\mathrm{r} \leq 4$ & $\mathrm{R}=5$ & 0.00016 & 0.0045 & 3.76 & 0.00016 & 0.0045 & 3.76 \\
\hline
\end{tabular}

Source: Own computation, 2017/18

- Trace Statistics and Maximum Eigen-value test indicates that there is 1 co-integrating equation at 5\% level.

- *Denotes rejection of the null hypothesis at the $5 \%$ level

The test result (both trace and max statistics) rejects the null hypothesis of no co-integration in both tests at the $5 \%$ significance level. In other words, the null of at most one co-integrating vector is not rejected because the Trace statistic and Maximum Eigen-value test is less than 0.05 Critical Value. Hence, there exist one co-integrating vectors which make up the long run relationship among the variables in the system. In this co-integration test only the long run relationship between variables are identified, this is the critics of the co-integration test and error correction model is used to capture this critics if co-integration by testing both the long run and short run association ship among the variables. As a result, the model LNSAV, LNRDGP, LNINV, LNCONSUP and INFL have a long run relationship and thus we are ordered to run VEC model to check the long run and short run association ship between the models.

\subsubsection{Vector Error Correction Model Tests}

Economic variables have short run behaviors that can be captured through dynamic modeling. If there is long run relationship among the variables which is identified through the co-integration test, an error correction model can being formulated that portray both the short run dynamic and long run interaction between the variables. In the previous discussion, it was shown that if two variables that are non-stationary in levels have a stationary linear 
combination then the two variables are co-integrated. It is checked in the above co-integration test that there is one co-integration vector. Co-integration means the presence of error correcting representation. That is, any deviation from the equilibrium point will revert back to its long run path. Therefore, an ECM depicts both the short run and long run behavior of a system.

\section{Diagnostic tests on the residual of the vector error correction model}

Tests of autocorrelation with the help of Durbin-Watson statistics, and normality on the residuals of the vector error correction models are conducted with the help of Jarque-Bera test. These tests are used to confirm the basic assumptions regarding the residual and the validity of the results in this study. From the tests, it was found that the nulls of no autocorrelation, and normality in the residuals could not be rejected and the model is going for the interpretation.

\section{The long run Relationship}

The co-integration rank test in the previous section suggests there is one co-integrating equation that defines saving as dependent variables. This study considers only on the co-integrating equation to examine the impact of other variables [real gross domestic product, investment, consumption and inflation] on saving. Therefore, the normalized co-integration equation is formulated in the following manner;

Table 4.3: Normalized Co-integrating coefficients (standard error in parentheses)

\begin{tabular}{lllll}
\hline LNSAV & LNRGDP & LNINV & LNCONSUP & INFL \\
1.000000 & -1.172941 & -0.1113186 & -7.752597 & -0.0086114
\end{tabular}
$(0.5181962)$
$(0.1434202)$
$(10.28428)$
$(0.0064141)$

Source: Own computation, 2017/18

Table:4.4.Co-integrating Coefficients Identification

\begin{tabular}{lll}
\hline Variables & Coefficient & Strd. Error \\
LNSAV & 1.000000 & \\
LNRGDP & -1.172941 & 0.5181962 \\
LNINV & -0.1113186 & 0.1434202 \\
LNCONSUP & -7.752597 & 10.28428 \\
INFL & -0.0086114 & 0.0064141 \\
Constant & -6.227435 & \\
\hline
\end{tabular}

Source: Own computation, 2017/18

The mathematical formulation of the above normalized equation is as follow;

LNSAV-1.172941.LNRGDP-0.1113186LNINV-7.752597LNCON-0.0086114INFL $=0$

$L N S A V=6.227435+1.172941 . L N R G D P+0.1113186 L N I N V+7.752597 L N C O N+0.0086114 I N F L$ is the long run normalized equation. The values of the coefficients are changed in sign, but not in magnitude when we equate to zero.

The interpretations of the coefficients have been forwarded as follows;

The estimation of the long-run model reveals that all explanatory variables (real gross domestic product, investment, consumption and inflation) positively determine the country's saving.

The RGDP coefficient is statistically significant. It reveals that there is positive relationship between saving and RGDP this is due to the reason that the improvement in the countries RGDP leads to the increment in the level of national income which in turn increases the level of saving. Therefore, if there is an increase in RGDP it will help to increase the national income and national saving. Therefore, a unit increase in RGDP of the country can improve saving by 1.172941 amounts on average.

The coefficient of investment is positive. This reveals that there is positive relationship between the investments and saving, this is due the reason that the improvement of investment of the county leads to the increment in the level of saving of country. Here from what expected as the saving of a nation grow up (income of a nation growth up), the demands of the investors of the country for the investment is relatively growth up which increase the income of the country. Therefore, a unit increase in investment of the country can increase saving by 0.1113186 amounts on average.

The equation reveals that the estimated long-run consumption level had a positive sign. Higher consumption have various economic effects: Increases the consumption level of the country decreases the saving level of a country as we expect but, this result of STATA shows to us as they have positive relationship in the long run. Therefore, a unit increase in consumption level of the country can increase saving by 7.752597 amounts on average.

Accordingly the equation reveals that the estimated long-run inflation rate had positive sign. Logically it seems like that inflation can affect saving level negatively but, our results show that as they have positive relationship in the long run. Therefore, a percentage increase in the inflation rate of the country can improve saving by 0.0086114 amounts on average 


\section{Short-Run Relationships}

After determining the existence of long run relationship among the variables, the next step is to set up the short run dynamic or the error correction model. It is obtained by estimating the first difference of the dependent variable on its own lag, on the first difference of all explanatory variables and their lags and also including one year lagged error term which is obtained from the long-run model estimation. The reason for including two year lag of the error term is to indicate how the time path matter to correct any error or deviation from the long run equilibrium. The change in the variables entered into the model to represent variation in the short run, while the coefficients obtained from the error correction term will represent the speed of adjustment towards the long run equilibrium relationship. As shown in the long run the existence of one co-integrating vector is supported by the Johansen cointegration test. This indicates that there is no problem of simultaneity. The following short run model is obtained. Table 4.5: The results for the Short run saving equation

\begin{tabular}{lccl}
\hline Variables & Coefficient & Std. Error & $\begin{array}{l}\text { Probability } \\
\text { (P-value) }\end{array}$ \\
C(1) OR ECTt-1 & -.768987 & .2297474 & 0.001 \\
C(2) OR LNSAV & .334458 & .2296263 & 0.145 \\
C(3) OR LNRGDP & -.8077423 & .8235401 & 0.327 \\
C(4) OR LNINV & .5215508 & .3395013 & 0.124 \\
C(5) OR LNCON & -5.572138 & 15.08965 & 0.712 \\
C(6) OR INFL & -.0040134 & .0053975 & 0.457 \\
C(7) OR CONS & .0540458 & .101738 & 0.595 \\
\hline SO
\end{tabular}

Source: Own computation, 2017/18

Here $\mathrm{C} 1$ is error correction term or speed of adjustment towards the equilibrium. It is the coefficient of cointegrating equation and the rest are coefficients of short run model, only C(7) is constant of the short run model.

There are two issues here, one- Long run Causality, and two- short run Causality. For the Long run Causality, if $\mathrm{C} 1$ is negative in sign and significant, then we can say that there is long run causality running from RGDP, investment, consumption and inflation rate to saving. But from the above table 4.5 only $\mathrm{C} 1$ coefficient have negative sign and significant. As a result there is a long run causality running from RGDP, investment, consumption and inflation rate to saving.

\section{Conclusion and Policy Implications}

Generally according to the econometric model result, national saving responded to real gross domestic product and investment on the theoretically expected way, But not for consumption and inflation. National saving related positively with RGDP, investment consumption and inflation. From the econometric model result, RGDP and investment are the most important factors which are significantly affect national saving in Ethiopia in relative to the other discussed determinants of national saving. Finally, national saving varied positively with all variables in periods, i.e long run and short run.

Consumption and national saving have insignificant impact. This is may be due to peoples misunderstanding. Many people think that they can save money after they consumed from their income, but this trend discourage peoples to save because there income may not be enough to consume. And saving should be taken as a necessity like that of consumption. As people consume monthly you must also save monthly. This must be taken as a habit.

In long run real gross product and national saving have positive relationship. So, to rise the national saving real gross domestic product is necessary and the producers should be encouraged by providing different incentives.

Incentives in the form of rewards for savers should be strengthened (for instance, this is being implemented by commercial bank of Ethiopia and Zeeman bank). This incentive and rewards motivates people to save more and increases the habit of saving which is one of the pillars of economic growth and development.

National investment and national saving have positive relationship in both periods. So, in order to increase national saving the concerned body should fulfill all the necessary condition for investors to promote national saving. Government policy towards investment should be favorable for both domestic and foreign investors which are the main source of income to be saved.

Government should take inflationary measures since inflation has insignificant impact on national saving in the short run. This can be taken place by the use of policy instruments like fiscal policy through expenditure and taxation. Here during a situation of inflation government shall use contractionary fiscal policy i.e. by decreasing government expenditure and increasing taxation.

\section{Reference}

Abu Girma (2004): The determinants of domestic saving in Ethiopia, paper presented on the second international conference on the Ethiopian economy, EEA, Ethiopia.

Ayele Kuris (2006): The Ethiopian Economy (principle and practice); $2^{\text {nd }}$ edition, Addis Ababa, Ethiopia

Claudio Paiva and SarwatJahan (2003): Determinants of national saving in Brazil,Brazil. 
Dayal-Ghulati and Thiman (1997); Saving in South East Asia and Latin America compared: searching for policy lessons, IMF.

Ethiopian Economics Association, (2001/20012); Annual report on the Ethiopian economy, Addis Ababa, Ethiopia. Loyza N., Lopez H., Schmidt-Hebbel and Serven L. (1999); The world saving database, World Bank, Washington DC.

Mankiew, N.G.(2000); Macroeconomics, $2^{\text {nd }}$ edition, Harvard University

Metain Ozcan Kilvicim (2000): Determinants of national saving in the Arab countries Iran and Turkey Ankar, Turkey.

Prema Chandra Athukroala (2003): Determinants of national saving in India, Australian national university, Canberra, Australia.

Said Hallaq, (2003): Determinants of national saving in Jordan, Ibid, Jordan.

SimenehZewdu, (2006); Determinants of national investment in Ethiopia, Addis Ababa, Ethiopia.

Tesema Aberu, Tewodros Ayalew and Tewodros Tefera, (2010) ;Determinants of inflation rate in Ethiopia

TochukwuE.Nwachukwu and Fastus D. Egwaikhide (2007); An error-correction model of the determinants of saving in Nigeria, Ibadad University,Nigeria. 